\title{
Productivity and Profitability of Direct Seeded Early $A$ hu Rice under Medium Land Situation
}

\author{
Dibyarishi Bhattacharjya $^{2}$, Krishna Bharadwaj ${ }^{1}$, Abhijit Sarma ${ }^{1 *}$, Kakali Konwar ${ }^{1}$, \\ Kushal Sarmah ${ }^{3}$, J.C. Das and Uddipana Shandilya ${ }^{4}$
}

\author{
${ }^{1}$ Department of Agronomy, Assam Agricultural University, Jorhat-785013, Assam, India \\ ${ }^{2}$ Krishi Vigyan Kendra, Napam, Tezpur -784028, Assam, India \\ ${ }^{3}$ Department of Agrometeorology, Assam Agricultural University, \\ Jorhat-785013, Assam, India \\ ${ }^{4}$ Department of Entomology, Assam Agricultural University, Jorhat-785013, Assam, India
}

*Corresponding author

\section{Keywords}

Direct seeded rice, Eary $a h u$, Irrigation, Nutrient management

Article Info

Accepted:

04 February 2019

Available Online:

10 March 2019

\section{A B S T R A C T}

A field experiment was carried out at the Instructional-cum-Research (ICR) Farm, Assam Agricultural University, Jorhat during 2017 to develop the irrigation schedule of direct seeded early $a h u$ rice under medium land situation and to find out the suitable nutrient management practices for direct seeded early $a h u$ rice to suit the variability in rainfall pattern. The treatments consisted of four irrigation regimes viz. irrigation at $80 \%$ available water till onset of pre-monsoon rain $\left(\mathrm{I}_{1}\right)$, irrigation at $70 \%$ available water till onset of premonsoon rain $\left(\mathrm{I}_{2}\right)$, irrigation at $60 \%$ available water till onset of pre-monsoon rain $\left(\mathrm{I}_{3}\right)$ and rainfed $\left(\mathrm{I}_{4}\right)$ as main plot and three nutrient management treatments viz. full $\mathrm{P}$ as basal $+1 / 2$ $\mathrm{N}$ and $1 / 2 \mathrm{~K}$ at 20 days after sowing (DAS) $+1 / 2 \mathrm{~N}$ and $1 / 2 \mathrm{~K}$ at 40 DAS $\left(\mathrm{N}_{1}\right)$, full $\mathrm{P}$ as basal, $1 / 3 \mathrm{~N}$ and $1 / 3 \mathrm{~K}$ as basal $+1 / 3 \mathrm{~N}$ and $1 / 3 \mathrm{~K}$ at $20 \mathrm{DAS}+1 / 3 \mathrm{~N}$ and $1 / 3 \mathrm{~K}$ at $40 \mathrm{DAS}\left(\mathrm{N}_{2}\right)$ and full $\mathrm{P}$ as basal, $1 / 2 \mathrm{~N}$ and $1 / 2 \mathrm{~K}$ as basal $+1 / 4 \mathrm{~N}$ and $1 / 4 \mathrm{~K}$ at $20 \mathrm{DAS}+1 / 4 \mathrm{~N}$ and $1 / 4 \mathrm{~K}$ at 40 DAS $\left(\mathrm{N}_{3}\right)$ as sub plot and control (transplanted early ahu rice with recommended water and fertilizer management practices). Experimental findings revealed that irrigation at $80 \%$ available water till onset of pre monsoon rain $\left(\mathrm{I}_{1}\right)$ recorded the highest values for all the morphological and physiological parameters along with the yield and yield attributing characters of the crop. The highest grain yield $(39.83 \mathrm{q} / \mathrm{ha})$ and straw yield $(90.96 \mathrm{q} / \mathrm{ha})$ were recorded at irrigation at $80 \%$ available water $\left(\mathrm{I}_{1}\right)$. Among the nutrient management practices, the highest values of all the morphological and physiological parameters along with the yield and yield attributing characters of the crop were recorded under full $\mathrm{P}$ as basal $+1 / 2 \mathrm{~N}$ and $1 / 2 \mathrm{~K}$ at 20 DAS $+1 / 2 \mathrm{~N}$ and $1 / 2 \mathrm{~K}$ at 40 DAS $\left(\mathrm{N}_{1}\right)$. This treatment also recorded the highest grain yield ( $34.16 \mathrm{q} / \mathrm{ha})$ and straw yield $(83.45 \mathrm{q} / \mathrm{ha})$. The experiment did not show any significant difference between direct seeded crop and transplanted crop with respect to growth parameters, yield attributes and yield. Direct seeded crop recorded the higher net return and benefit-cost ratio over the transplanted rice. 


\section{Introduction}

Rice is a staple crop for nearly half of the world's seven billion people (Mohanty, 2013). It is a staple food of Assamese of all ages, influencing the cropping pattern of the state (Talukdar and Deka, 2005). The crop occupies about two-third of the gross cropped area of the state. Three rice crops are grown in a year i.e. autumn, winter and summer. Direct seeded early $a h u$ rice is grown under rainfed condition while transplanted early $a h u$ rice is grown with irrigation facilities. There are three principal methods of direct seeded rice (DSR) viz. dry seeding (sowing dry seeds into dry soil), wet seeding (sowing pregerminated seeds in wet puddled soil) and water seeding (seeds sown into standing water). Dry seeding has been the principal method of establishment (Akhgari and Kaviani, 2011).

The rice cultivation system is affected by water deficient, less suitable land and shortages of labourer (Nguyen and Ferrero, 2006). Direct seeded rice is a major opportunity to change production practices to attain optimal plant density and high water productivity in water scarce areas. Adoption of direct seeded rice for lowland rice culture would significantly decrease costs of rice production (Flinn and Mandac, 1986). Dry seeding reduces the overall water demand of rice by reducing water needed for land preparation, losses due to evaporation, leaching, percolation etc. (Bouman and Tuong, 2001). Direct seeded rice (DSR) is a technology which does not require any specialized farm implements and it can be sown using the same seed drill in more or less same manner as other crops such as wheat. Labour use on a DSR plot is about $50 \%$ less than on non DSR plots. In the face of increasing population and growing demand for food the upgrading of rainfed areas through DSR technology can help in soil and water conservation and deal with risks arising from climate change. With this ideas in mind, this investigation was planned to develop the irrigation schedule and to find out the suitable nutrient management practices of direct seeded early $a h u$ rice under medium land situation to suit the variability in rainfall pattern.

\section{Materials and Methods}

The present experiment was conducted to study the effect of direct seeding on productivity and profitability of early $a h u$ rice on the basis of direct seeded rice production technology under medium land situation. The field experiment was conducted during the $a h u$ season at Instructional-cum-Research (ICR) Farm, Assam Agricultural University, Jorhat-13. The ICR Farm is situated at $26^{\circ} 47^{\prime}$ $\mathrm{N}$ latitude, $94^{\circ} 12^{\prime} \mathrm{E}$ longitude and at an altitude of 87.0 meter above mean sea level. The climatic condition of Jorhat is subtropical humid with hot summer and cold winter. Normally, monsoon starts from the month of June and continues up to the month of September with the occurrence of low premonsoon showers from mid March. The intensity of rainfall decreases from the month of October and reaches minimum during December-January. During the entire period of investigation, the total amount of rainfall received was $768.0 \mathrm{~mm}$ with a maximum average weekly rainfall of $115.9 \mathrm{~mm}$ on $26^{\text {th }}$ March to $1^{\text {st }}$ April, 2017. The weekly mean maximum temperature ranged from $26.6^{\circ} \mathrm{C}$ to $14.9^{\circ} \mathrm{C}$ and weekly mean minimum temperature ranged from $26.1^{\circ} \mathrm{C}$ to $14.4^{\circ} \mathrm{C}$. The weekly average relative humidity ranged from 96.6 per cent to 90.4 per cent during the morning hours and 82.1 per cent to 44.3 per cent in the evening hours. The highest weekly bright sunshine hours was recorded in the month of April (7.4 hours/day) and lowest in the month of June (1.6 hours/day). The weekly mean evaporation varied from 
$2.1 \mathrm{~mm} /$ day to $4.2 \mathrm{~mm} /$ day during the study period. The soil of the experimental plot was silt loam in texture, acidic in reaction having $\mathrm{pH} 5.2$, organic carbon $7.2 \mathrm{~g} / \mathrm{kg}$, alkaline KMnO4 extractable N $181.0 \mathrm{~kg} / \mathrm{ha}$, Brays-I P $10.7 \mathrm{~kg} / \mathrm{ha}$ and $1 \mathrm{~N}$ ammonium acetate extractable K $227.9 \mathrm{~kg} / \mathrm{ha}$. It contained soil moisture $27.6 \%$ at $-0.03 \mathrm{MPa}$ and $9.6 \%$ at $1.5 \mathrm{MPa}$ with bulk density of $1.34 \mathrm{~g} / \mathrm{cc}$. The rice variety "Inglongkiri" was sown on $18^{\text {th }}$ February, 2017. The control treatment with recommended water and nutrient management practice was transplanted on $17^{\text {th }}$ March, 2017.

The experiment was laid out in split plot design with 3 replications and 13 treatments. The main plot treatment included irrigation schedule viz. $\mathrm{I}_{1}$ : Irrigation at $80 \%$ available water till onset of pre-monsoon rain, $\mathrm{I}_{2}$ : Irrigation at $70 \%$ available water till onset of pre-monsoon rain, $\mathrm{I}_{3}$ : Irrigation at $60 \%$ available water till onset of pre-monsoon rain and $\mathrm{I}_{4}$ : rainfed. The subplot treatment included nutrient management viz. $\mathrm{N}_{1}$ : Full $\mathrm{P}$ as basal $+1 / 2 \mathrm{~N} \& 1 / 2 \mathrm{~K}$ at $20 \mathrm{DAS}+1 / 2 \mathrm{~N} \& 1 / 2$ $\mathrm{K}$ at 40 DAS, $\mathrm{N}_{2}$ : Full $\mathrm{P}$ as basal \& $1 / 3 \mathrm{~N} \&$ $1 / 3 \mathrm{~K}$ as basal $+1 / 3 \mathrm{~N} \& 1 / 3 \mathrm{~K}$ at $20 \mathrm{DAS}+$ $1 / 3 \mathrm{~N} \& 1 / 3 \mathrm{~K}$ at $40 \mathrm{DAS}, \mathrm{N}_{3}$ : Full $\mathrm{P}$ as basal and $1 / 2 \mathrm{~N}$ and $1 / 2 \mathrm{~K}$ as basal $+1 / 4 \mathrm{~N}$ and $1 / 4 \mathrm{~K}$ at 20 DAS $+1 / 4 \mathrm{~N}$ and $1 / 4 \mathrm{~K}$ at 40 DAS A control treatment i.e. transplanted early $a h u$ rice with recommended water and fertilizer management practices was included. Recommended dose of fertilizer @ 40-20-20 as $\mathrm{N}-\mathrm{P}_{2} \mathrm{O}_{5}-\mathrm{K}_{2} \mathrm{O} \mathrm{kg} / \mathrm{ha}$ was applied in the form of urea, SSP and MOP. Fertilizers were applied as per treatment. In control plot, full $\mathrm{P}_{2} \mathrm{O}_{5}$ and $\mathrm{K}_{2} \mathrm{O}$ and half $\mathrm{N}$ were applied as basal. One fourth $\mathrm{N}$ was applied at maximum tillering and one fourth $\mathrm{N}$ was applied at panicle initiation stage. The sowing was done manually by line sowing with seed rate 75 $\mathrm{kg} / \mathrm{ha}$. On the same day, seeds were soaked to sow in nursery bed for transplanting in control plot with seed rate $45 \mathrm{~kg} / \mathrm{ha}$. Seedlings were transplanted on 17th March, 2017 by maintaining a spacing of $20 \mathrm{~cm} \times 15 \mathrm{~cm}$ in the control plot. Two weedings were done at 3 weeks and 6 weeks after sowing by manual hoeing to reduce the ill effect of weeds which makes the environment unfavorable for growth of rice. In transplanted crop, Japanese Paddy Weeder was operated after top dressing of urea to incorporate the fertilizer as well as to control the weeds. Irrigation was applied as per treatment. In each plot, $5 \mathrm{~cm}$ irrigation water was applied when water level depleted to a certain level as per treatment. Then the grain and straw yields were measured separately in $\mathrm{kg}$ per plot and converted to $\mathrm{kg}$ per ha (at 14\% moisture content in grain).

The data were analyzed statistically and the mean differences among the treatment means were evaluated by the least significance difference (LSD) at 5\% level of probability (Sarma, 2016). For economic analysis, all input costs including the cost for lease of land and interest on running capital were considered for computing the cost of production. The benefit-cost ratio was computed by dividing gross return by total cost of cultivation.

\section{Results and Discussion}

\section{Growth characters}

The morphological characteristics of the plant like number dry matter accumulation, Crop Growth Rate (CGR), and Leaf Area Index (LAI) showed marked differences under various irrigation and nutrient management management practices (Table 1 and Fig. 1, 2 \& 3). Significantly the highest dry matter accumulation at 60 DAS and at harvest was obtained with irrigation at $80 \%$ available water till onset of pre-monsoon rain $\left(\mathrm{I}_{1}\right)$. This treatment also recorded the highest Leaf Area Index (LAI), however it was at par with irrigation at $70 \%$ available water till onset of 
pre-monsoon rain $\left(\mathrm{I}_{2}\right)$ at 60 DAS. Growth in terms of crop growth rate (CGR) was observed to be improved with irrigation at $80 \%$ available water $\left(\mathrm{I}_{1}\right)$ which might be ascribed to increased photosynthetic surface and biomass accumulation by the crop (Yoshida et al., 1981). In the present study, better growth parameters under this treatment could be due to the maintenance of soil moisture at or near field capacity. On the other hand, when irrigation was applied at $30 \%\left(\mathrm{I}_{2}\right)$ and $40 \%\left(\mathrm{I}_{3}\right)$ depletion of available water, it resulted in more drying period and evaporative demand of the crop was not adequately fulfilled. The rainfed crop suffered from moisture stress as the crop received the first rainfall $(9.8 \mathrm{~mm})$ at $18 \mathrm{DAS}$. Up to 29 DAS, the crop did not received sufficient rainfall which could meet the crop water demand. Thus, growth parameters under these treatments were relatively lower than irrigation applied at $80 \%$ available water. Soil drying not only limits root water uptake which can (but not always) perturb shoot water status, but also alters synthesis of phytohormones by root and their transport to shoots to regulate leaf growth and gas exchange. Re-wetting the soil rapidly restores leaf water potential and leaf growth (minutes to hours), but gas exchange recovers more slowly (hours to days), probably mediated by sustained changes in root to shoot phytohormonal signaling (Dodd et al., 2015). The increased growth parameters in irrigation at $80 \%$ available water $\left(\mathrm{I}_{1}\right)$ might be due to higher moisture availability which favoured development of plant infrastructure. Rainfed crop could not compete with the irrigated treatments due to reduction in soil moisture content much below the field capacity. These findings are in harmony with those reported by Shekara et al., (2010) and Dass and Dhar (2014).

The effect of different nutrient management practices on morphological parameters barring plant height was found to be statistically significant for all the growth stages. Application of full $\mathrm{P}$ as basal $+1 / 2 \mathrm{~N}$ and $1 / 2 \mathrm{~K}$ at $20 \mathrm{DAS}+1 / 2 \mathrm{~N}$ and $1 / 2 \mathrm{~K}$ at 40 DAS $\left(\mathrm{N}_{1}\right)$ being at par with full $\mathrm{P}$ as basal \& $1 / 3 \mathrm{~N} \& 1 / 3 \mathrm{~K}$ as basal $+1 / 3 \mathrm{~N} \& 1 / 3 \mathrm{~K}$ at 20 $\mathrm{DAS}+1 /{ }_{3} \mathrm{~N} \& 1 / 3 \mathrm{~K}$ at $40 \mathrm{DAS}$ recorded the highest dry matter accumulation and LAI at 60 DAS and at harvest. This might be due to the split application of nitrogen and potassium at right time with greater synchrony between crop demand and nutrient supply. Yoshida et al., (1981) also reported that nitrogen should be supplied at about 20 days before heading, if it is very limited. When the supply is moderate, nitrogen may be given twice viz. at the early growth stages and at about 20 days before heading. When nitrogen is abundant, application of $\mathrm{N}$ at early growth stages are most efficient for grain production. Applying nitrogen at about 20 days before heading has a high productive efficiency when the level is moderate or low. This period coincides with the active growth of young panicles before heading. The absorbed nitrogen at this time is efficiently used to increase spikelet number and hence, panicle size. For this reason, topdressing at panicle initiation is called Hogoe in Japanese, implying panicle fertilizer. For soils with low nitrogen-holding capacity, split applications of fertilizer resulted in a higher nitrogen recovery and, hence, a higher yield than a basal application.

\section{Yield attributes and yield}

The significant variation in growth characteristics as a result of differential application of irrigation and nutrient management further led to marked variation in yield attributes of rice crop. In the present study, rice crop with irrigation at $80 \%$ available water $\left(\mathrm{I}_{1}\right)$ produced higher yield attributes than that with the crop irrigation at $70 \%$ and $60 \%$ available water $\left(I_{2}\right.$ and $\left.I_{3}\right)$ and without irrigation $\left(\mathrm{I}_{4}\right)$ (Table 2 ). It could be 
inferred from results of present investigation that irrigation to direct seeded crop at $80 \%$ available water $\left(\mathrm{I}_{1}\right)$ involving three irrigations at 12, 23 and 34 DAS maintained favourable soil moisture condition for better growth and development and partitioning of photosynthates and dry matter to seed. The highest grain yield and straw yield being 39.83 and $90.96 \mathrm{q} / \mathrm{ha}$, respectively was recorded from irrigation at $80 \%$ available water $\left(\mathrm{I}_{1}\right)$. This treatment produced 14.7, 25.7 and 36.7 per cent higher yield than irrigation at $70 \%$ and $60 \%$ available water $\left(I_{2}\right.$ and $\left.I_{3}\right)$ and rainfed crop $\left(\mathrm{I}_{4}\right)$. Higher seed yield under irrigation at $80 \%$ available water might be attributed to the higher values of various yield components under the treatment. The decrease in grain and straw yield in other treatments was due to the decreased soil water content as a result of differential irrigation schedules. There was a consistent trend of decline in grain and straw yield as the irrigation threshold increased. Lower yield of direct seeded rice under greater water deficit might be due to lower number of grains/panicle and lower effective tillers $/ \mathrm{m}^{2}$. Similar results were reported by McDonald et al., (2005), Kukal et al., (2010) and Naresh et al., (2013). In the present study, yield of direct seeded rice was at par with transplanted rice. Kabat (2012) also reported that rice growth and yield were statistically similar under direct seeding and transplanting conditions.

Table.1 Effect of irrigation schedule and nutrient management on plant height, dry matter and leaf area index of rice

\begin{tabular}{|c|c|c|c|c|c|c|}
\hline \multirow[t]{2}{*}{ Treatments } & \multicolumn{2}{|c|}{$\begin{array}{c}\text { Plant height at } \\
\text { harvest }\end{array}$} & \multicolumn{2}{|c|}{ Dry matter $\mathbf{m}^{-2}$} & \multicolumn{2}{|c|}{ Leaf Area Index } \\
\hline & $\begin{array}{l}\text { At } 60 \\
\text { DAS }\end{array}$ & At harvest & At 60 DAS & At harvest & $\begin{array}{l}\text { At } 60 \\
\text { DAS }\end{array}$ & At harvest \\
\hline \multicolumn{7}{|c|}{ Irrigation Schedule (I) } \\
\hline$I_{1}$ & 45.8 & 141.6 & 597.0 & 1310.4 & 4.9 & 2.5 \\
\hline $\mathbf{I}_{2}$ & 45.3 & 137.1 & 527.0 & 1173.9 & 4.4 & 2.2 \\
\hline $\mathbf{I}_{3}$ & 44.8 & 135.8 & 516.9 & 1086.9 & 3.7 & 1.5 \\
\hline $\mathbf{I}_{4}$ & 44.1 & 134.9 & 501.8 & 1038.2 & 2.0 & 1.1 \\
\hline SEm \pm & 1.7 & 4.6 & 17.9 & 40.0 & 0.1 & 0.1 \\
\hline $\mathrm{CD}_{0.05}$ & NS & NS & 58.2 & 130.4 & 0.5 & 0.2 \\
\hline \multicolumn{7}{|c|}{ Nutrient Management (N) } \\
\hline $\mathrm{N}_{1}$ & 45.7 & 139.4 & 570.1 & 1241.6 & 4.8 & 2.4 \\
\hline $\mathbf{N}_{2}$ & 45.6 & 136.7 & 540.1 & 1141.9 & 4.5 & 2.3 \\
\hline $\mathbf{N}_{3}$ & 43.8 & 135.9 & 496.8 & 1073.8 & 2.1 & 0.8 \\
\hline $\mathrm{SEm} \pm$ & 1.4 & 3.9 & 12.4 & 34.4 & 0.1 & 0.1 \\
\hline $\mathrm{CD}_{0.05}$ & NS & NS & 37.3 & 103.1 & 0.3 & 0.15 \\
\hline $\begin{array}{l}\text { Interaction } \\
(\mathbf{I} \times \mathbf{N})\end{array}$ & NS & NS & NS & NS & NS & NS \\
\hline \multicolumn{7}{|c|}{ Control vs treatment } \\
\hline Treatment & 45.0 & 137.4 & 535.7 & 1152.4 & 3.8 & 1.8 \\
\hline Control & 39.8 & 135.3 & 548.4 & 1183.3 & 4.0 & 1.9 \\
\hline SEm \pm & 3.1 & 8.3 & 32.2 & 72.1 & 0.27 & 0.12 \\
\hline $\mathrm{CD}(\mathrm{P}=\mathbf{0 . 0 5})$ & NS & NS & NS & NS & NS & NS \\
\hline
\end{tabular}


Table.2 Effect of irrigation schedule and nutrient management on yield attributes and grain and straw yield of rice

\begin{tabular}{|c|c|c|c|c|c|c|c|c|}
\hline Treatments & $\begin{array}{l}\text { Effective } \\
\text { tillers/m }\end{array}$ & $\begin{array}{l}\text { No. of } \\
\text { grains } \\
\text { /panicle }\end{array}$ & $\begin{array}{c}1000 \\
\text { seed } \\
\text { weight } \\
\text { (g) }\end{array}$ & $\begin{array}{c}\text { Grain } \\
\text { yield } \\
\text { (q/ha) }\end{array}$ & $\begin{array}{c}\text { Straw } \\
\text { yield } \\
\text { (q/ha) }\end{array}$ & $\begin{array}{c}\text { Harvest } \\
\text { index }\end{array}$ & $\begin{array}{c}\text { Net } \\
\text { Return } \\
(₹)\end{array}$ & $\begin{array}{l}\mathrm{B}: \mathrm{C} \\
\text { ratio }\end{array}$ \\
\hline \multicolumn{9}{|c|}{ Irrigation Schedule (I) } \\
\hline $\mathbf{I}_{1}$ & 186.1 & 97.3 & 24.1 & 39.83 & 90.96 & 30.5 & 34937.17 & 2.20 \\
\hline $\mathbf{I}_{2}$ & 165.6 & 95.3 & 24.1 & 34.72 & 79.90 & 30.3 & 27369.00 & 1.96 \\
\hline $\mathbf{I}_{3}$ & 154.1 & 90.0 & 24.1 & 31.68 & 74.30 & 29.9 & 22989.00 & 1.82 \\
\hline $\mathbf{I}_{4}$ & 142.3 & 86.5 & 24.0 & 29.14 & 72.30 & 28.7 & 19589.17 & 1.71 \\
\hline SEm \pm & 5.8 & 2.8 & 0.5 & 1.30 & 2.99 & 0.9 & - & - \\
\hline $\mathrm{CD}_{0.05}$ & 18.8 & 9.3 & NS & 4.24 & 9.74 & NS & - & - \\
\hline \multicolumn{9}{|c|}{ Nutrient management $(\mathrm{N})$} \\
\hline $\mathrm{N}_{1}$ & 173.8 & 98.2 & 24.1 & 37.16 & 83.45 & 30.8 & 31483.75 & 2.11 \\
\hline $\mathbf{N}_{2}$ & 163.1 & 92.6 & 24.1 & 33.54 & 79.36 & 29.7 & 26153.13 & 1.92 \\
\hline $\mathbf{N}_{3}$ & 149.2 & 86.1 & 24.0 & 30.83 & 75.30 & 29.0 & 21026.38 & 1.74 \\
\hline SEm \pm & 4.1 & 2.0 & 0.5 & 1.08 & 2.54 & 0.80 & - & - \\
\hline SEm \pm & 12.2 & 6.10 & NS & 3.24 & 7.61 & NS & - & - \\
\hline $\mathrm{CD}_{0.05}$ & NS & NS & NS & NS & NS & NS & - & - \\
\hline $\begin{array}{c}\text { Interaction } \\
(\mathbf{I} \times \mathbf{N})\end{array}$ & NS & NS & NS & NS & NS & NS & - & - \\
\hline \multicolumn{9}{|c|}{ Control vs treatment } \\
\hline Treatment & 162.0 & 92.3 & 24.1 & 33.84 & 79.37 & 29.9 & 31483.75 & 2.11 \\
\hline Control & 166.3 & 96.6 & 24.1 & 37.04 & 81.53 & 31.2 & 19212.10 & 1.48 \\
\hline SEm \pm & 10.42 & 5.13 & 0.97 & 2.34 & 5.39 & 1.69 & - & - \\
\hline $\mathrm{CD}(\mathrm{P}=0.05)$ & NS & NS & NS & NS & NS & NS & - & - \\
\hline
\end{tabular}

Fig.1 Effect of irrigation schedule on Crop Growth Rate (CGR) at different growth stages of rice

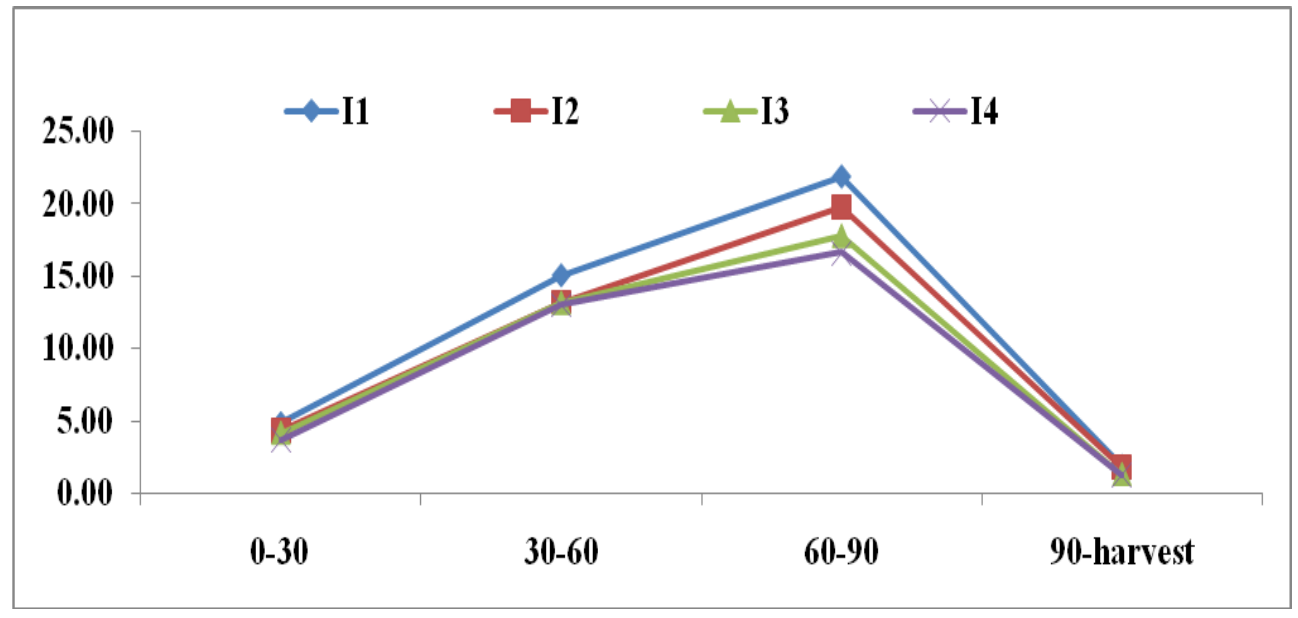


Fig.2 Effect of nutrient management on Crop Growth Rate (CGR) at different growth stages of rice

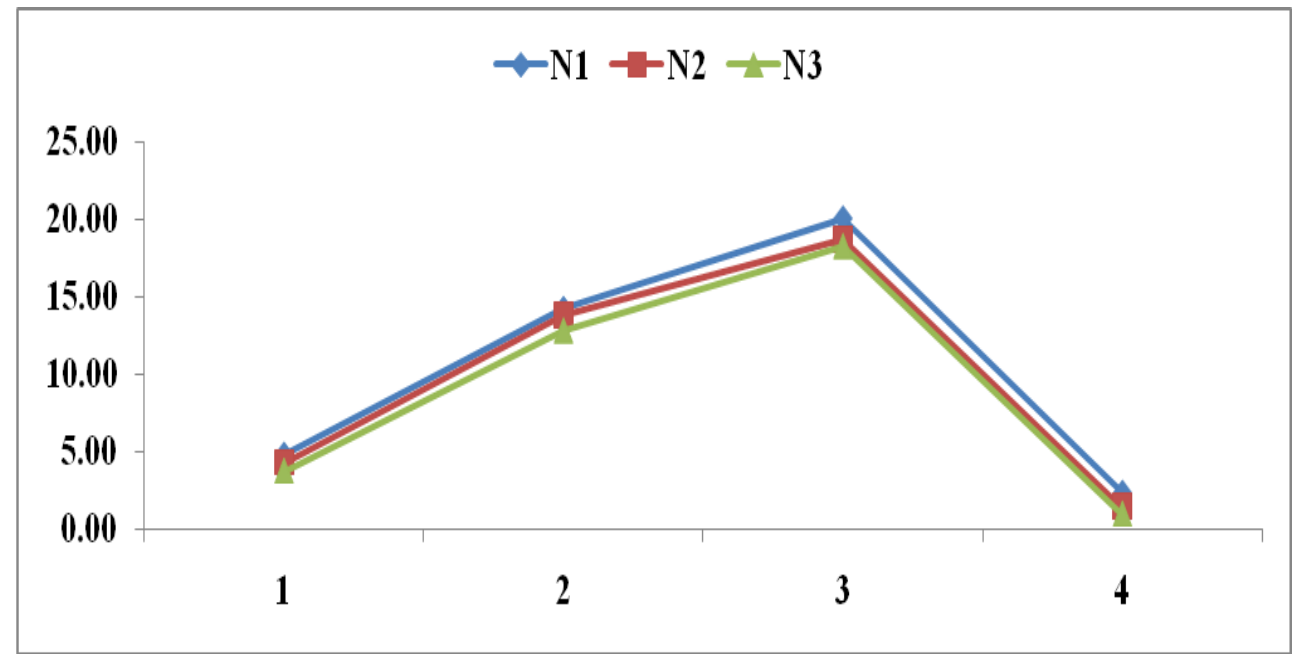

Fig.3 Crop Growth Rate (CGR) at different growth stages of rice (Control vs treatment)

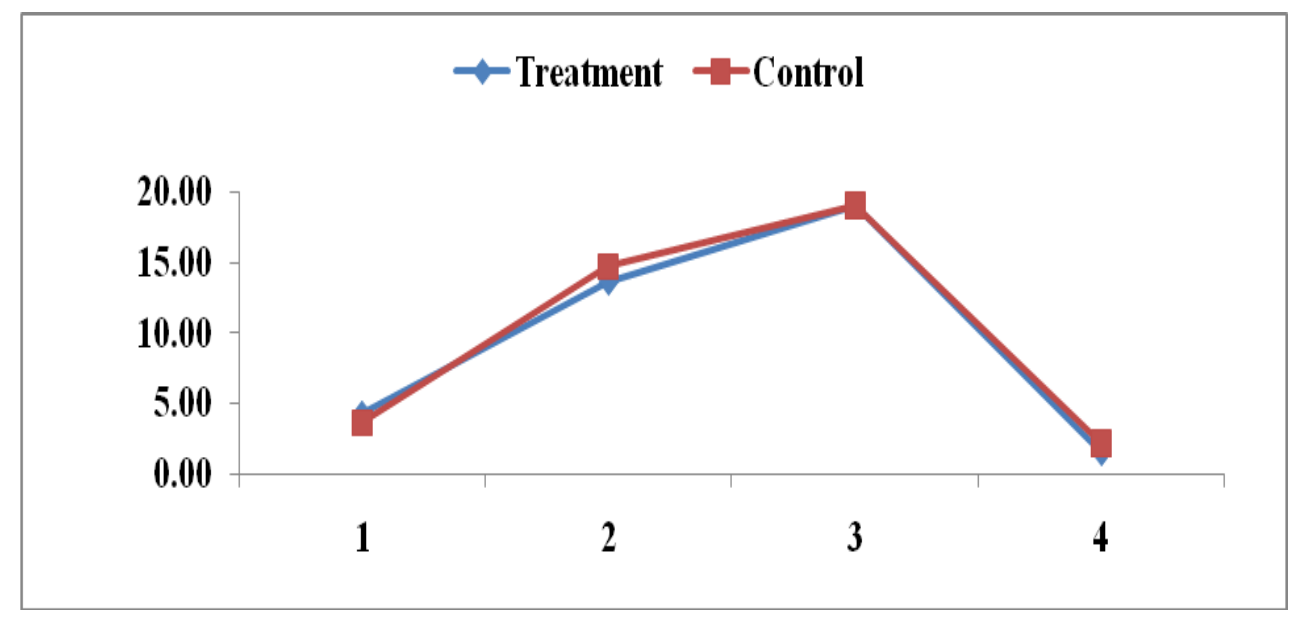

The seed and stover yield increased significantly with two splits of $\mathrm{N}$ and $\mathrm{K}$ at 20 and 40 DAS $\left(\mathrm{N}_{1}\right)$ than 3 splits $\left(\mathrm{N}_{2}\right.$ and $\left.\mathrm{N}_{3}\right)$. Two splits of $\mathrm{N}$ and $\mathrm{K}$ at 20 and $40 \mathrm{DAS}\left(\mathrm{N}_{1}\right)$ recorded higher yield attributing characters of direct seeded rice than 3 splits $\left(\mathrm{N}_{2}\right.$ and $\left.\mathrm{N}_{3}\right)$. The effective response to $\mathrm{N}$ and $\mathrm{K}$ application sets in when level of $\mathrm{N}$ and $\mathrm{K}$ satisfies the hunger in soil and the soil expected to behave. In the present experiment, two splits of $\mathrm{N}$ and $\mathrm{K}$ satiated the soil hunger more than 3 splits. Similar results were reported by Ravichandran (2011).

\section{Economics}

The irrigation at $80 \%$ available water $\left(\mathrm{I}_{1}\right)$ recorded the highest net return ( $₹ 34937.17$ ) and benefit-cost ratio (2.20). This is due to higher crop yield and relatively less production cost. On the other hand transplanted crop recorded the lowest net return ( $₹ 19212.1)$ and benefit-cost ratio (1.48) due to higher cost of production. The major determinant of cost of production is labour, water and fertilizers in rice cultivation. Omission of puddling saved considerable 
labour and water costs. Sahrawat et al., (2009) also observed 13-16\% labour savings in direct seeded rice systems. Among the nutrient management treatments, full $\mathrm{P}$ as basal $+1 / 2 \mathrm{~N}$ and $1 / 2 \mathrm{~K}$ at 20 DAS $+1 / 2 \mathrm{~N}$ and $1 / 2$ $\mathrm{K}$ at 40 DAS $\left(\mathrm{N}_{1}\right)$ recorded the highest net return (₹ 31483.75) and benefit-cost ratio (2.11) due to higher crop yield with same level of production cost. Collateral findings have been reported by Kumar et al., (2009).

Thus, under medium land situation, there is possibility of growing rice by direct seeding instead of transplanting. Under direct seeded condition, crop should be irrigated at $80 \%$ available water till onset of pre monsoon rain. Entire recommended dose of $\mathrm{P}_{2} \mathrm{O}_{5}(20 \mathrm{~kg} / \mathrm{ha})$ should be applied as basal. Half of the recommended dose of $\mathrm{N}(10 \mathrm{~kg} / \mathrm{ha})$ and $\mathrm{K}_{2} \mathrm{O}$ (10 kg/ha) should be top dressed at 20 days after sowing. Rest half of the recommended $\mathrm{N}$ (10 kg/ha) and $\mathrm{K}_{2} 0(10 \mathrm{~kg} / \mathrm{ha}$ ) should be top dressed at 40 days after sowing.

\section{References}

Akhgari, H. and Kaviani, B. (2011). Assessment of direct seeded and transplanting method of rice cultivars in the northern part of Iran. African Journal of Agricultural Research 6(31): 6492-6498.

Bouman, B.A.M. and Tuong, T.P. (2001). Field water management to save water and increase its productivity in irrigated lowland rice. Agricultural Water Management 49: 11-30.

Dass, A. and Dhar, S. (2014). Irrigation management for improving productivity, nutrient uptake and water-use efficiency in system of rice intensification: a review. Annals of Agricultural Research 35(2): 107-122.

Dodd, I.C., Puertolas, J., Huber, K., PerezPerez, J.G., Wright, H.R. and Blackwell, M.S.A. (2015). The importance of soil drying and rewetting in crop phytohormonal and nutritional responses to deficit irrigation. Journal of Experimental Botany 66(8): 2239-2252.

Flinn, J.C. and Mandac, A.M. (1986). Wet seeding of rice in less favored rainfed environments In: Working paper, Agricultural Economics Department, International Rice Research Institute, Los Banos, Philippines.

Kabat, S. (2012). Influence of farm yard manure, brown manuring and levels of nitrogen on yield and quality parameters of direct seeded and transplanted rice. Oryza. 49(3): 231233.

Kukal, S.S., Yadav, S., Humphrey, E., Kaura, A., Singh, Y., Thaman, S., Singh, B. and Timsina, J. (2010). Factors affecting irrigation water savings in raised beds in rice and wheat. Field Crops Research 118: 43-50.

Kumar, V., Ladha, J.K. and Gathala, M.K. (2009). Direct drill-seeded rice: A need of the day. Annual Meeting of Agronomy Society of America, Pittsburgh, November 1-5, 2009 (http://a-c s.confex.com/crops/2009am/ webprogram/Paper 53386.html).

McDonald, A.J., Riha, S.J., Duxbury, J.M. and Steenhious, T.S. (2005). Water balance and rice growth responses to direct seeding, deep tillage and landscape placement : Findings from a valley terrain in Nepal. Field Crops Research 95: 367-382.

Mohanty, S. (2013). Trends in global rice production. Rice Today 12(1): 44-45.

Naresh, R.K., Mishra, A.K. and Singh, S.P. (2013). Assessment of direct seeded and transplanting method of rice cultivars in the western part of Uttar Pradesh. International Journal of Pharmaceutical Sciences and Business 
Management 1(1): 1-8.

Nguyen, N.V. and Ferrero, A. (2006). Meeting the challenges of global rice production. Paddy Water Environment 4: 1-9.

Ravichandran, M. (2011). Optimizing timing and potassium application in productivity enhancement of crops. Karnataka Journal of Agricultural Sciences 24 (1): 75-80.

Shekara, B.G., Sharnappa, K. and Krishnamurthy, N. (2010). Effect of irrigation schedules on growth and yield of aerobic rice (Oryza sativa L.) under varied levels of farmyard manure in Cauvery command area. Indian Journal of Agronomy 55(1): 35-39.

Talukdar, K.C. and Deka, B.C. (2005). Cultivation of summer rice in the flood plains of Assam - an assessment of economic potential on marginal and small farms. Agricultural Economics Research Review 18: 21-38.

Yoshida, S., Satake, T. and Mackill, D. (1981). High-temperature stress in rice. IRRI Research Paper Series 67: $1-15$.

\section{How to cite this article:}

Dibyarishi Bhattacharjya, Krishna Bharadwaj, Abhijit Sarma, Kakali Konwar, Kushal Sarmah, J.C. Das and Uddipana Shandilya. 2019. Productivity and Profitability of Direct Seeded Early Ahu Rice under Medium Land Situation. Int.J.Curr.Microbiol.App.Sci. 8(03): 269-277. doi: https://doi.org/10.20546/ijcmas.2019.803.034 